\title{
Influence of Amino Acid Supplementations in Juvenile Yellow Perch Fed Plant Protein Combinations
}

\author{
Aaron J. Von Eschen"1,2, Michael L. Brown1, Kurt Rosentrater ${ }^{3}$ \\ ${ }^{1}$ Department of Natural Resource Management, South Dakota State University, Brookings, SD, USA \\ ${ }^{2}$ U.S. Fish and Wildlife Service, Valley City National Fish Hatchery, Valley City, ND, USA \\ ${ }^{3}$ Department of Agricultural and Biosystems Engineering, Iowa State University, Ames, IA, USA \\ Email: michael.brown@sdstate.edu
}

How to cite this paper: Eschen, A.J.V. Brown, M.L. and Rosentrater, K. (2019) Influence of Amino Acid Supplementations in Juvenile Yellow Perch Fed Plant Protein Combinations. Open Journal of Animal Sciences, 9, 183-195.

https://doi.org/10.4236/ojas.2019.92016

Received: January 17, 2019

Accepted: March 26, 2019

Published: March 29, 2019

Copyright (C) 2019 by author(s) and Scientific Research Publishing Inc. This work is licensed under the Creative Commons Attribution International License (CC BY 4.0).

http://creativecommons.org/licenses/by/4.0/

\begin{abstract}
Distillers dried grains with solubles (DDGS) in combination with soy protein concentrate (SPC) with and without an essential amino acid (EAA) complex were assessed as protein alternatives in juvenile Yellow Perch Perca flavescens diets. Diets contained 5\% FM, 40\% SPC, and 20\% or 40\% DDGS each with or without EAA. No mortalities or health assessment differences were observed during the trial and all fish readily accepted the experimental diets. Diets supplemented with EAA produced greater weight gain, improved feed conversion, and apparent protein digestibility. Performance was consistently improved for fish fed diets containing amino acid supplements. Based on these results, Yellow Perch are able to utilize high levels of the plant proteins, accompanied with EAAs, as a FM replacer.
\end{abstract}

\section{Keywords}

Yellow Perch, Fish Nutrition, Distillers Dried Grains with Solubles, Soy Protein Concentrate, Amino Acids

\section{Introduction}

A primary concern for aquaculture production is the development of cost-effective feeds, and is a constraining factor that hampers the rapidly growing global aquaculture industry [1] [2]. Feed ingredient prices, such as fishmeal (FM) are following an increasing cost trend; however, FM production will likely remain static [3]. Fish meal is the traditional animal protein used in fish feeds [4] and generally accounts for the most expensive ingredient in fish diets, translating into one of the largest expenditures in aquaculture production [2] [5] [6]. Prices for 
FM have risen sharply since 2008 and since 2014 have fluctuated around $\$ 1500$ per metric ton (Index Mundi.com 2018). As a result, less costly plant and animal alternatives are included to reduce costs [7]. However, plant-based ingredients often contain anti-nutritional factors (ANF), are less digestible, and do not offer the same balance of amino acids that FM provides [2]. With the increased demand for feed supplies to support culture of existing and new species for the food fish market, it is vital that feeds research continues to evolve with a focus on sustainable, less costly energy-protein and lipid-ingredients. Substitution of FM with plant products will become more common as these plant products become available in large quantities and processing methods improve nutrient composition, palatability and digestibility, and decrease ANFs.

Corn ethanol production has increased over 160 percent since 2000 from 1.6 billion to 15.8 billion gallons in 2017 [8]. With the increase in ethanol production, the availability of distillers dried grains with solubles (DDGS) has increased. An expected annual production of 40 million metric tons will eventually be produced by the U.S. fuel ethanol industry providing a readily available feed source to developing markets, especially in the Midwest Corn Belt where most ethanol plants are located [9]

DDGS are a corn fermentation coproduct derived from ethanol production that typically yields protein ranging from $27 \%$ to $31 \%$ [10] [11] [12] [13], and lipid ranges from $8 \%$ to12\% [12]. Several studies have tested DDGS in aquaculture feeds [3] [14]-[20]. Only one study to date [21] has investigated the use of DDGS in Yellow Perch diets, and some success was found.

Similarly, numerous soybean feedstuffs have been evaluated and are available for aquaculture and considered important ingredients in many freshwater fish diets [22] [23]. Generally, defatted SBM has been the most commonly tested soybean feedstuff, however, some studies have tested SPC supplementation in fish diets [24] [35]. Kasper et al. [36] and Schaeffer et al. [21] are the only known published studies that have evaluated soybean ingredients in Yellow Perch diets.

Reducing the cost of fish feeds by replacing FM with plant-based proteins is anticipated to reduce production costs, given the lower commodity pricing. Such replacements are not direct, because plant-based proteins often have an inferior essential amino acid (EAA) composition when compared to FM [37] [38] and may have several ANFs [22] [23] [36] [38] [39]. Thus, mixed plant-based proteins along with EAA supplements may be required to achieve a balance in compound feeds that more closely mimics the nutritional profile of FM to meet production objectives and control operating costs. The objective of this study was to evaluate Yellow Perch performance fed diets that included mixed blends of DDGS and SPC in Yellow Perch diets, with and without amino acid supplements.

\section{Methods}

Experimental Diets.-Four experimental feeds were formulated to incorporate FM (70\% crude protein; $9.7 \%$ lipid), SPC (73\% crude protein; $0 \%$ lipid), and 
$20 \%$ or $40 \%$ DDGS (29\% crude protein; $11.9 \%$ lipid) (Table 1). Each DDGS level was formulated for testing with and without an essential amino acid (EAA) complex (arginine, lysine, isoleucine, histidine, glycine, methionine, and a sulfonic acid-taurine). EAA deficiencies of experimental diets were determined a priori from feedstuff analyses and minimum EAA concentrations for inclusion were conformed to recommended levels suggested for Yellow Perch by Hart et al. [41]. Diets were formulated to contain similar crude protein levels $(46.7 \pm 0.84$ $[$ mean $\pm \mathrm{SE}])$ and gross energy $(13.75 \pm 0.32 \mathrm{MJ} / \mathrm{kg})$ (Table 2). Gross energy

Table 1. Diet formulations (dry matter basis, g/100 g) containing menhaden fish meal (FM), soy protein concentrate (SPC), and distiller's dried grain with solubles (DDGS).

\begin{tabular}{|c|c|c|c|c|}
\hline \multirow[b]{2}{*}{ Ingredients (\%) } & \multicolumn{4}{|c|}{ Diets } \\
\hline & 1 & 2 & 3 & 4 \\
\hline Menhaden FM ${ }^{\mathrm{a}}$ & 5.0 & 5.0 & 5.0 & 5.0 \\
\hline DDGS $^{\mathrm{b}}$ & 20.0 & 20.0 & 40.0 & 40.0 \\
\hline $\mathrm{SPC}^{\mathrm{c}}$ & 40.0 & 40.0 & 40.0 & 40.0 \\
\hline Whole wheat flour ${ }^{\mathrm{d}}$ & 10.0 & 10.0 & 2.0 & 2.0 \\
\hline Corn gluten meal ${ }^{\mathrm{e}}$ & 5.0 & 5.0 & 2.0 & 2.0 \\
\hline Menhaden oil ${ }^{\mathrm{a}}$ & 5.0 & 5.0 & 3.1 & 3.1 \\
\hline Celufil $^{\mathrm{f}}$ & 10.0 & 6.5 & 3.0 & 0.0 \\
\hline Vitamin premix ${ }^{g}$ & 0.5 & 0.5 & 0.5 & 0.5 \\
\hline Ascorbic acid (Stay-C $)^{\mathrm{e}}$ & 0.05 & 0.05 & 0.05 & 0.05 \\
\hline Choline chloride $^{e}$ & 0.2 & 0.2 & 0.2 & 0.2 \\
\hline Mineral premix ${ }^{\mathrm{h}}$ & 0.1 & 0.1 & 0.1 & 0.1 \\
\hline Sodium chloride ${ }^{e}$ & 1.0 & 1.0 & 1.0 & 1.0 \\
\hline Potassium chloride $^{\mathrm{e}}$ & 0.8 & 0.8 & 0.8 & 0.8 \\
\hline Magnesium oxide $e^{e}$ & 0.05 & 0.05 & 0.05 & 0.05 \\
\hline Calcium phosphate $^{\mathrm{e}}$ & 2.0 & 2.0 & 2.0 & 2.0 \\
\hline Phytase $^{\mathrm{i}}$ & 0.037 & 0.037 & 0.037 & 0.037 \\
\hline Amino acid complex ${ }^{\mathrm{jk}}$ & 0.0 & $\underline{4.0}$ & 0.0 & $\underline{4.0}$ \\
\hline Arg & -- & 0.3 & -- & 0.3 \\
\hline His & -- & 0.2 & -- & 0.2 \\
\hline Ile & -- & 0.1 & -- & 0.1 \\
\hline Lysine & -- & 0.5 & -- & 0.5 \\
\hline Met & -- & 0.5 & -- & 0.5 \\
\hline Glx & -- & 0.5 & -- & 0.5 \\
\hline Tau (sulfonic acid) & -- & 0.5 & -- & 0.5 \\
\hline
\end{tabular}

${ }^{a}$ Omega Protein, Inc., Houston, TX, USA; 'Poet Ethanol, Chancellor, SD, USA; 'The Solae Company, St. Louis, MO, USA; 'Bob's Red Mill Natural Foods, Inc., Milwaukie, OR, USA; ${ }^{\mathrm{e}}$ Consumers Supply Distributing Company, Sioux City, IA, USA; ${ }^{\mathrm{f} U S B}$ Corporation, Cleveland, OH, USA; ${ }^{\mathrm{g}}$ ARS 720 Vitamin Premix, USDA Agricultural Research Service, USA [40]; ' $A R S 640$ Trace Mineral Premix, USDA Agricultural Research Service, USA [40]; ' Ronozyme P, DSM Nutritional Products, Ames, IA, USA; 'Arg, DL-Arginine; His, DL-Lysine; Ile, DL-Isoleucine; His, DL-Histidine; Glx, DL-Glutamine; Met, DL-Methionine; Tau, DL-Taurine; ${ }^{k}$ Pure Bulk, Inc., Roseburg, OR, USA. 
Table 2. Diet composition analyses (g/100 g, db). Gross energy (GE) was estimated as crude protein $\times 23.6 \mathrm{MJ} / \mathrm{kg}+$ crude fat $\times 39.5 \mathrm{MJ} / \mathrm{kg}$ (NRC 2011). Analysis was conducted on post-extrusion pellets. Amino acid requirements are estimated (EST) values from Hart et al. (2010).

\begin{tabular}{|c|c|c|c|c|c|}
\hline \multicolumn{6}{|c|}{ Diets } \\
\hline Component (\%) & $\underline{1}$ & $\underline{2}$ & $\underline{3}$ & $\underline{4}$ & $\underline{\text { EST }}$ \\
\hline Crude protein & 44.59 & 47.23 & 46.52 & 48.62 & \\
\hline Arginine & 2.71 & 2.91 & 2.7 & 2.91 & 2 \\
\hline Histidine & 1.06 & 1.22 & 1.11 & 1.25 & 0.9 \\
\hline Isoleucine & 1.89 & 2.01 & 1.94 & 2.04 & 1.4 \\
\hline Leucine & 3.79 & 3.78 & 3.84 & 3.76 & 2.3 \\
\hline Lysine & 2.38 & 2.8 & 2.44 & 2.82 & 2.6 \\
\hline Methionine & 0.64 & 1.04 & 0.66 & 1.06 & 0.8 \\
\hline Phenylalanine & 2.15 & 2.18 & 2.2 & 2.17 & 1.4 \\
\hline Threonine & 1.63 & 1.6 & 1.67 & 1.64 & 1.4 \\
\hline Tryptophan & 0.62 & 0.64 & 0.65 & 0.63 & 0.3 \\
\hline Valine & 2.07 & 2.1 & 2.16 & 2.16 & 1.6 \\
\hline EAA sum & 18.94 & 20.28 & 19.37 & 20.44 & \\
\hline Crude lipid & 6.11 & 6.67 & 7.09 & 7.61 & \\
\hline Crude fiber & 1.98 & 1.94 & 2.88 & 2.82 & \\
\hline GE (MJ/kg dry matter) & 12.94 & 13.78 & 13.78 & 14.48 & \\
\hline
\end{tabular}

values were estimated using energy density values $17.2,23.6$, and $39.5 \mathrm{MJ} / \mathrm{kg}$ for carbohydrates, proteins, and lipids, respectively, multiplied by the composition amounts for each ingredient (Table 2) [2].

Feed were processed using a single screw, autogenous extruder (Bepex International LLC, Minneapolis, Minnesota), with a barrel length of $600 \mathrm{~mm}$, a barrel length to diameter ratio of four, and barrel speed of $228 \mathrm{rpm}$. Feeds were extruded into $2-\mathrm{mm}$ diameter pellets, dried at room temperature, coated with fish oil, crumbled and sieved to achieve uniform pellet size, and stored at $-20^{\circ} \mathrm{C}$. Diets were analyzed for crude protein (AOAC 2006, method 990.03), crude fat (AOAC 2006, method 990.03), crude fiber (AOAC 2006, method 978.10), moisture (AOAC 2006, method 934.01), and ash (AOAC, method 942.05) and amino acids [AOAC 2006, method $982.30 \mathrm{E}(\mathrm{a}, \mathrm{b}, \mathrm{c})$ ].

Fish and Culture System.-Age-0 Yellow Perch were held in a 340-L flow-through system and feed trained to accept a commercial pelleted diet (BioDiet Grower, Bio-Oregon, Longview, Washington) for a period of 60 days. Following the feed training interval, $288(10.8 \pm 0.6 \mathrm{~g})$ fish were randomly stocked into 16, 110-L tanks to provide four replicate experimental units per diet. Total tank weights $( \pm 0.5 \mathrm{~g})$ were measured and a random subsample of 25 fish was selected for initial individual length $( \pm 1 \mathrm{~mm})$ and weight $( \pm 0.1 \mathrm{~g})$ measurements. Fish were fed the commercial diet for an additional two-week acclimation period 
then diet treatments were randomly assigned to replicate tanks.

The feeding trial was conducted in a closed loop recirculation system consisting of a solids separation tank, bio-reactor, and $100-\mu \mathrm{m}$ bag, charcoal, and UV filtration. Water turnover rate was 25 times per 24 hour period. Water temperature was held constant at $23^{\circ} \mathrm{C}$ with a $1800 \mathrm{w}$ single phase bayonet heater (Process Technology, Mentor, Ohio). Double-backed foil insulation was wrapped around culture tanks to help maintain water temperatures. Half-tank covers were used to minimize disturbances. Fecal and uneaten feed solids were removed daily with a siphon to maintain water quality. Nitrite (Hach 2008, method 8153), nitrate (Hach 2008, method 8039), and ammonia (Hach 2008, method 8038) nitrogens were measured weekly using a Hach DREL 2000 Spectrophotometer (Hach Company, Loveland, CO, USA). Water $\mathrm{pH}$ was measured weekly using an Oakton multi-parameter PCS Testr 35 (Eutech Instruments, Vernon Hills, Illinois). Dissolved oxygen (DO) was measured twice weekly using an YSI Model 55 DO meter (Yellow Springs Instrument Corp., Yellow Springs, Ohio).

Water quality remained stable throughout the duration of the trial. Water $\mathrm{pH}$ levels varied from 8.0 - 8.6 during the trial. Un-ionized free ammonia (calculated from total ammonia nitrogen) ranged from $0.003-0.01 \mathrm{mg} / \mathrm{L}$. Nitrate-nitrogen ranged from $2.6-6.2 \mathrm{mg} / \mathrm{L}$. Nitrite-nitrogen ranged from $0.02-0.05 \mathrm{mg} / \mathrm{L}$. Water temperatures were held constant at $23^{\circ} \mathrm{C}$ and photoperiod was maintained at $15 \mathrm{~h}$ light: $9 \mathrm{~h}$ dark for the duration of the feeding trial.

Fish were hand-fed rations of $2.0 \%-2.75 \%$ of tank biomass, split into two feedings daily. Consumption was monitored daily to ensure satiation feeding, estimate feed intake, and to minimize feed waste. Total tank weights were measured every 21 days and feed rations were adjusted according to tank weight and observed consumption. Upon completion of the feeding trial, total tank weights were measured as well as individual lengths and weights. Five randomly selected fish from each treatment were euthanized with MS-222, pending necropsy.

Fish Analyses.-Performance indices were used to determine responses to treatment diets. Percent weight gain was calculated as WG $=100 \times$ (final weight (g) - initial weight $(\mathrm{g})$ )/initial weight $(\mathrm{g}))$ [2]. Feed conversion ratio was calculated as FCR $=$ (weight of diet fed (g)/total wet weight gain (g)) [2]. Protein efficiency ratio was calculated as PER $=$ (weight gain (g)/protein fed (g)) [2]. Consumption was measured as total feed fed minus feed remaining during the feeding trial.

General health and condition indices were determined from necropsy data including viscerosomatic index [VSI $=($ visceral weight $(\mathrm{g}) /$ body weight $(\mathrm{g})) \times$ 100], hepatosomatic index [HSI $=($ liver weight $(\mathrm{g}) /$ body weight $(\mathrm{g})) \times 100]$, and muscle ratio $[\mathrm{MR}=(($ fillet weight $(\mathrm{g}) \times 2) /$ body weight $(\mathrm{g})) \times 100]$ [2]. Fulton-type condition factor was calculated $\left[K=\left(\mathrm{W} / \mathrm{L}^{3}\right) \times 100,000\right]$ using individual lengths and weights.

Proximate analysis was determined on the fillets including crude protein (AOAC 2006, Method 990.03), crude fat (AOAC, Method 990.03), crude fiber (AOAC 2006, Method 978.10), moisture (AOAC 2006, Method 934.01) and ash 
(AOAC, Method 942.05). Amino acid profiles were completed on individual fillets (AOAC 2006, Method $982.30 \mathrm{E}$ (a, b, c)).

Statistical Analysis.-All response variables were analyzed using analysis of variance (ANOVA) to assess DDGS inclusion levels and amino acid supplementation treatment effects. Significant ANOVA results $(p \leq 0.05)$ were further analyzed with Tukey's range tests to determine mean differences [42]. SYSTAT (version 11) software (SPSS Inc. Chicago, Illinois) and Microsoft Excel (Microsoft, Redmond, Washington) were used to perform all statistical analyses.

\section{Results}

Fish readily accepted the experimental diets and fed actively consuming all feed at $2 \%$ of tank weight per day. No mortalities or nutritional deficiencies were observed during the trial and no fish exhibited any disease symptoms.

A significant difference was observed in weight gain $(F=18.9$, df $3,12, P<$ $0.01)$ (Table 3). Weight gain was highest for fish fed diets 2 (20\% DDGS + EEA) and 4 (40\% DDGS + EAA) regardless of DDGS inclusion level. Only diet $1(20 \%$ DDGS) did not produce $100 \%$ weight gain by the conclusion of the trial. Feed conversion ratio was also significantly different $(F=25.5$, df $3,12, P<0.01)$ among treatments. Fish fed diet 4 (40\% DDGS + EAA) had the most favorable FCR followed by diet 2 (20\% DDGS + EEA); diet 1 (20\% DDGS) had the least favorable FCR. A significant difference was also detected in PER ( $F=15.3$, df 3 , $12, P>0.01$ ) following a pattern among treatments similar to FCR (Table 3 ).

Diet composition had no significant effect on $\operatorname{MR}(F=1.6$, df 3, 12, $P=0.23)$. No significant differences were detected among HSI values $(F=0.8, \mathrm{df} 3,12, P=$ $0.53)$. The VSI values were significantly different $(F=3.8$, df $3,12, P=0.04)$ being highest in fish fed diets containing 40\% DDGS, indicating larger fat deposits with higher DDGS inclusion. Fulton-type condition factor ( $K$ values) was also significantly different $(F=4.0$, df $3,12, P=0.04)$ and, highest for fish fed diet 4 (40\% DDGS + EAA).

Post-hoc amino acid analysis of the diets revealed that only diets containing EAA supplements completely met or exceeded the suggested EAA required for Yellow Perch reported by Hart et al. [41] (Table 2). Diets without EAA failed to

Table 3. Mean tank weight gain (WG), feed conversion ratio (FCR), protein efficiency ratio (PER), viscerosomatic index (VSI), hepatosomatic index (HSI), Fulton-type condition factor $(\mathrm{K})$, muscle ratio (MR) of Yellow Perch fed experimental diets. Values are treatment means $( \pm \mathrm{SE})$ for response variables. Values not significantly different $(P>0.05)$ have the same letter within a given column.

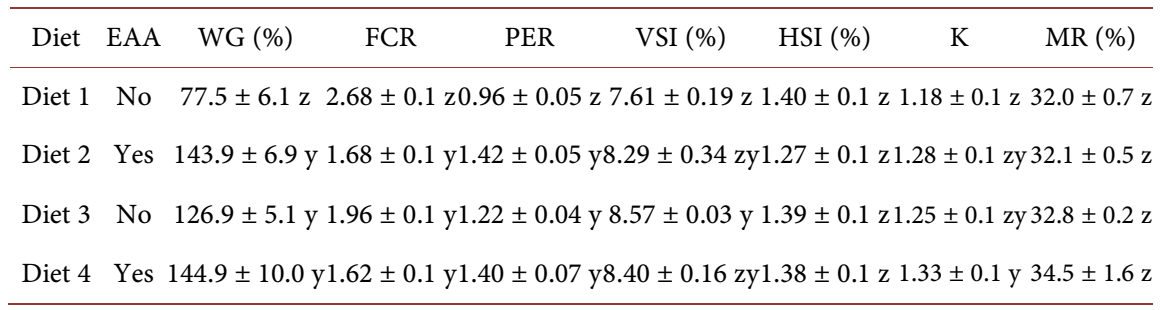


reach the minimum requirement for lysine and methionine. Proximate analysis showed that diet 4 (40\% DDGS + EAA) had the highest crude protein while diet 1 (20\% DDGS) had the lowest (Table 2). Analysis of muscle tissue revealed no statistical differences in muscle EAA concentrations (Table 4).

\section{Discussion}

Rinchard et al. [43] [44] stated that Yellow Perch readily accepted and consumed prepared FM diets and juveniles could be successfully weaned with prepared diets. However, their diets contained FM as the primary protein source. In this study, all fish readily accepted and actively consumed diets with largely plant-based proteins.

No mortalities or signs of nutritional deficiencies occurred during the feeding trial, indicating that the Yellow Perch are able to utilize these combinations of plant ingredients. Schaeffer et al. [21] had nearly 100\% survival (two mortalities) when testing combinations of DDGS and SBM in experimental diets fed to Yellow Perch. Kasper et al. [36] tested soybean feedstuffs in two different forms of SBM (solvent extracted, dehulled SBM and expelled-extruded SBM) in the diets of Yellow Perch and although mortality rates increased as SBM increased survival remained above $90 \%$. Those findings, along with current results suggest Yellow Perch will utilize diets containing high amounts of plant products in conjunction with FM, and performance improves when EAA are included as demonstrated in this study.

Table 4. Resulting amino acid and proximate composition (\%, dry matter basis) of Yellow Perch fillets. Values not significantly different $(p>0.05)$ have the same letter within a given row.

\begin{tabular}{ccccc}
\hline Amino Acid & Diet 1 & Diet 2 & Diet 3 & Diet 4 \\
\hline Arginine & $5.65 \pm 0.09 \mathrm{z}$ & $5.64 \pm 0.16 \mathrm{z}$ & $5.76 \pm 0.16 \mathrm{z}$ & $5.50 \pm 0.08 \mathrm{z}$ \\
Histidine & $2.88 \pm 0.05 \mathrm{z}$ & $2.85 \pm 0.10 \mathrm{z}$ & $2.93 \pm 0.08 \mathrm{z}$ & $2.80 \pm 0.07 \mathrm{z}$ \\
Isoleucine & $4.49 \pm 0.10 \mathrm{z}$ & $4.41 \pm 0.09 \mathrm{z}$ & $4.58 \pm 0.13 \mathrm{z}$ & $4.36 \pm 0.05 \mathrm{z}$ \\
Leucine & $7.71 \pm 0.14 \mathrm{z}$ & $7.65 \pm 0.18 \mathrm{z}$ & $7.86 \pm 0.24 \mathrm{z}$ & $7.48 \pm 0.12 \mathrm{z}$ \\
Lysine & $9.01 \pm 0.17 \mathrm{z}$ & $8.91 \pm 0.20 \mathrm{z}$ & $9.17 \pm 0.28 \mathrm{z}$ & $8.79 \pm 0.15 \mathrm{z}$ \\
Methionine & $2.93 \pm 0.06 \mathrm{z}$ & $2.91 \pm 0.09 \mathrm{z}$ & $2.98 \pm 0.11 \mathrm{z}$ & $2.85 \pm 0.07 \mathrm{z}$ \\
Phenylalanine & $4.14 \pm 0.07 \mathrm{z}$ & $4.08 \pm 0.11 \mathrm{z}$ & $4.21 \pm 0.11 \mathrm{z}$ & $4.03 \pm 0.06 \mathrm{z}$ \\
Threonine & $4.00 \pm 0.05 \mathrm{z}$ & $3.99 \pm 0.10 \mathrm{z}$ & $4.06 \pm 0.17 \mathrm{z}$ & $3.85 \pm 0.10 \mathrm{z}$ \\
Tryptophan & $1.24 \pm 0.06 \mathrm{z}$ & $1.15 \pm 0.03 \mathrm{z}$ & $1.15 \pm 0.02 \mathrm{z}$ & $1.13 \pm 0.02 \mathrm{z}$ \\
Valine & $4.74 \pm 0.12 \mathrm{z}$ & $4.63 \pm 0.07 \mathrm{z}$ & $4.76 \pm 0.13 \mathrm{z}$ & $4.73 \pm 0.07 \mathrm{z}$ \\
Crude Protein & 94.30 & 92.84 & 93.40 & 91.89 \\
Crude Fat & 3.66 & 3.92 & 3.98 & 4.68 \\
Crude Fiber & 0.15 & 0.08 & 0.05 & 0.05 \\
Ash & 8.12 & 7.56 & 7.50 & 7.99 \\
\hline
\end{tabular}


Results from this study demonstrate that Yellow Perch are able to effectively use combinations of DDGS and SPC as FM protein replacers and perform better when supplemented with EAA. Weight gain was significantly higher when diets contained $40 \%$ DDGS and when EAA were supplemented at both $20 \%$ and $40 \%$ DDGS. Fish fed either diet with EAA displayed at least 140\% weight gain. Similarly, Kwasek et al. [45] found that Yellow Perch growth improved when feeding wheat gluten-based diets supplemented with lysine.

Schaeffer et al. [21] showed that Yellow Perch had greatest growth when fed diets containing 40\% DDGS + 9.5 SBM + 24\% FM, but noted that growth decreased significantly after DDGS was incorporated at 50\% DDGS. Similar studies have had success in using combinations of DDGS and soybean feedstuffs in other species. Nile Tilapia Oreochromis niloticus were fed diets containing 35\% DDGS $+58 \%$ soy flour producing growth most similar to that of a commercial diet [15]. DDGS was used to replace up to $30 \%$ SBM, along with lysine supplements, without significantly affecting growth in Channel Catfish Ictalurus punctatus [44]. The authors of that study also reported that weight gain was highest for diets containing DDGS + SBM as opposed to diets testing cottonseed meal (CSM) with either DDGS or SBM. Similar results was seen in a study by Gaylord and Barrows [46] who found that Rainbow Trout diets incorporating plant based proteins with EAA supplements at two different protein (35\%, 45\%) levels had increased performance over un-supplemented diets. The authors noted that greater improvements were observed in diets containing the lower protein level. Furuya et al. [47] found that FM can be completely replaced by SBM when supplemented with EAA (Lys, Met, Thr, Trp, Arg, Phe, His, Ile, Leu, Val) in the diets of Nile Tilapia.

EAA supplements had a positive impact on FCR and PER values of diets in this study. Similar results have been reported for other cultured species fed DDGS and soybean feedstuffs with amino acid supplements. An increase in FCR was observed for Rainbow Trout when lysine and methionine were incorporated [7]. Likewise, increased FCR and PER values were observed in both juvenile and yearling Red Sea Bream Pragus major fed diets containing SPC when lysine and methionine were incorporated [29]. Davies and Morris [37] found Rainbow Trout PER improved when EAA supplements were added to soy-based diets, however multiple EAA (met, lys, try, thr, arg, his) supplements proved to provide higher PER than diets containing just methionine and lysine supplements. In this study, PER was significantly lower in fish fed the diet containing 20\% DDGS without EAA (Table 3), no difference was observed in fish fed diets containing EAA or $40 \%$ DDGS.

Condition ( $K$ values) was significantly higher in fish fed diet 4 (40\% DDGS + EAA), however, fish fed diets with EAA had higher $K$ values when compared to the paired EAA-restricted diets. A similar trend was observed with DDGS inclusion, when DDGS were incorporated at $40 \%$ the $K$ values were higher than when compared with the paired diets. These results are similar to those observed by 
Schaeffer et al. [21] where the authors determined that Yellow Perch $K$ values remained high when DDGS were included in the diet up to $40 \%$, however lower $K$ values were observed when DDGS reached $50 \%$ inclusion. These results indicate that Yellow Perch condition is supported up to a 40\% DDGS inclusion and that EAAs support an even more favorable condition level.

Based on the somatic tissue analysis, Yellow Perch incorporated dietary EAAs into muscle at similar concentrations regardless of whether or not the diets were supplemented with additional EAA (Table 4). Proximate analysis revealed fillet crude protein was lower for fish fed diets with EAA when compared to diets without additional EAAs. Crude lipid levels in the muscle tissue was found to be higher in diets supplemented with EAA and diets with higher DDGS (Table 4), but diets containing 40\% DDGS had the highest crude protein levels. Even though no significant differences were apparent, diets supplemented with EAA or $40 \%$ DDGS had higher MR than diets without supplements (Table 3). Schaeffer et al. [21] reported similar results in which no difference was observed in MR when Yellow Perch were fed various combinations of DDGS and SBM.

No significant difference was observed in HSI values indicating that plant protein or EAA inclusion had no impact on relative liver size. Schaeffer et al. [21] noted that HSI values increased as SBM decreased and DDGS increased, HSI values in their study were overall higher than in this study. Takagi et al. [29] determined that HSI of Red Sea Breamfed SPC-based diets was most similar to those fed a FM-based diet when lysine and methionine were supplemented in the diet. VSI values differed significantly in diet 1 and diet 3, however did not appear to be affected by EAA supplements (Table 2). Schaeffer et al. [21] reported no differences in VSI values regardless of DDGS and SBM inclusion when fed to Yellow Perch.

\section{Conclusion}

In summary, Yellow Perch were able to effectively utilize the DDGS and SPC combinations presented in this study, although when added EAA supplementation improved performance characteristics. In general, performance was better when DDGS were incorporated at $40 \%$; however, concentration did not appear to be a factor when EAA was added to the diets. In the case of 20\% DDGS with EAA supplements, results were nearly the same as those provided by diets including 40\% DDGS with EAAs. SPC appears to be a suitable alternative to replacing FM when combined with corn-based proteins. These results along with those of Kasper et al. [36] and Schaeffer et al. [21] demonstrate that plant-based proteins can be used as the primary source of protein in Yellow Perch diets.

\section{Acknowledgements}

The authors thank the South Dakota Soybean Research and Promotion Council, South Dakota Agriculture Experiment Station, Department of Natural Resource Management at South Dakota State University, and the South Dakota Department of Game, Fish and Parks for funding, facilities, equipment, and supplies. 
Furthermore, we appreciated the technical support provided by S. Nichols, K. Mjoun, and several undergraduate students.

\section{Conflicts of Interest}

The authors declare no conflicts of interest regarding the publication of this paper.

\section{References}

[1] Hardy, R.W. (2008) Farmed Fish Diet Requirements for the Next Decade and Implications for Global Availability of Nutrients. In: Lim, C.E., Webster, C.D. and Sheng-Lee, C., Eds., Alternative Protein Sources in Aquaculture Diets, The Haworth Press, Inc., Binghamton, New York, 1-15.

[2] National Research Council (NRC) (2011) Nutrient Requirements of Fish and Shrimp.

[3] Zhou, F., Song, W., Shao, Q., Peng, X., Xiao, J., Hua, Y. and Owari, B.N. (2011) Partial Replacement of Fish Meal by Fermented Soybean Meal in Diets for Black Sea Bream, Acanthopagrus schegelii, Juveniles. Journal of the World Aquaculture Society, 42, 184-197. https://doi.org/10.1111/j.1749-7345.2011.00455.x

[4] Abdelghany, A.E. (2003) Partial and Complete Replacement of Fish Meal with Gambusiameal in Diets for Red Tilapia Oreochromis niloticus $\times$ O. mossambicus. Aquaculture Nutrition, 9, 145-154. https://doi.org/10.1046/j.1365-2095.2003.00234.x

[5] Lim, C., Yildirim-Aksoy, M. and Klesius, P.H. (2009) Growth Response and Resistance to Edwardsiella ictaluri of Channel Catfish, Ictalurus punctatus, Fed Diets Containing Distiller's Dried Grains with Solubles. Journal of the World Aquaculture Society, 40, 182-193. https://doi.org/10.1111/j.1749-7345.2009.00241.x

[6] Kop, A. and Korkut, A.Y. (2010) Effects of Diets with Different Fish Meal Origins on the Performance of Rainbow Trout Oncorhynchus mykiss (Walbaum). Journal of Animal and Veterinary Advances, 9, 581-583. https://doi.org/10.3923/javaa.2010.581.583

[7] Cheng, Z.J., Hardy, R.W. and Blair, M. (2003) Effects of Supplementing Methionine Hydroxyl Analogue in Soybean Meal and Distiller's Dried Grain-Based Diets on the Performance and Nutrient Retention of Rainbow Trout [Oncorhynchus mykiss (Walbaum)]. Aquaculture Research, 34, 1303-1310. https://doi.org/10.1046/j.1365-2109.2003.00940.x

[8] RFA. (2018) Building Bridges to a More Sustainable Future: 2018 Ethanol Industry Outlook. Renewable Fuels Association, Washington DC. https://ethanolrfa.org/wp-content/uploads/2015/09/RFA_Outlook_2011.pdf

[9] Rosentrater, K.A. (2012) Overview of Fuel Ethanol Production and Distillers Grains. In: Liu, K. and Rosentrater, K.A., Eds., Distillers Grains, Production, Properties, and Utilization, CRC Press, Boca Raton, Florida, 7-34.

[10] Cromwell, G.L., Herkleman, K.L. and Stahly, T.S. (1993) Physical, Chemical, and Nutritional Characteristics of Distillers Dried Grains with Solubles for Chicks and Pigs. Journal of Animal Science, 71, 679-686. https://doi.org/10.2527/1993.713679x

[11] Speihs, M.J., Whitney, M.H. and Shurson, G.C. (2002) Nutrient Database for Distiller's Dried Grains with Solubles Produced from New Ethanol Plants in Minnesota and South Dakota. Journal of Animal Science, 80, 2639-2645. 
[12] Belyea, R.L., Rausch, K.D. and Tumbleson, M.E. (2004) Composition of Corn and Distillers Dried Grains with Solubles from Dry Grind Ethanol Processing. Bioresource Technology, 94, 293-298. https://doi.org/10.1016/j.biortech.2004.01.001

[13] Liu, K. (2008) Particle Size Distribution of Distillers Dried Grains with Solubles (DDGS) and Relationships to Compositional and Color Properties. Bioresource Technology, 99, 8421-8428. https://doi.org/10.1016/j.biortech.2008.02.060

[14] Webster, C.D., Tidwell, J.H., Goodgame, L.A. and Johnsen, P.B. (1993) Growth, Body Composition, and Organoleptic Evaluation of Channel Catfish Fed Diets Containing Different Percentages of Distiller's Grains with Solubles. Progressive Fish-Culturist, 55, 95-100. https://doi.org/10.1577/1548-8640(1993)055<0095:GBCAOE >2.3.CO;2

[15] Wu, Y.V., Rosati, R.R. and Brown, P.B. (1996) Effect of Diets Containing Various Levels of Protein and Ethanol Coproducts from Corn on Growth of Tilapia Fry. Journal of Agricultural and Food Chemistry, 44, 1491-1493. https://doi.org/10.1021/jf950733g

[16] Wu, Y.V., Rosati, R.R. and Brown, P.B. (1997) Use of Corn-Derived Ethanol Products and Synthetic Lysine and Tryptophan for Growth of Tilapia (Oreochromis niloticus) Fry. Journal of Agricultural and Food Chemistry, 45, 2174-2177. https://doi.org/10.1021/jf960880u

[17] Coyle, S.D., Mengel, G.J., Tidwell, J.H. and Webster, C.D. (2004) Evaluation of Growth, Feed Utilization, and Economics of Hybrid Tilapia, Oreochromis niloticusx Oreochromis aureus, Fed Diets Containing Different Protein Sources in Combination with Distillers Dried Grains with Solubles. Aquaculture Research, 35, 365-370. https://doi.org/10.1111/j.1365-2109.2004.01023.x

[18] Cheng, Z.J. and Hardy, R.W. (2004) Nutritional Value of Diets Containing Distiller's Dried Grains with Solubles for Rainbow Trout, Oncorhynchus mykiss. Journal of Applied Aquaculture, 15, 101-113. https://doi.org/10.1300/J028v15n03_08

[19] Thompson, K.R., Rawles, S.D., Metts, L.S., Smith, R., Wimsatt, A., Gannam, A.L., Twibell, R.G., Johnson, R.B., Brady, Y.J. and Webster, C.D. (2008) Digestibility of Dry Matter, Protein, Lipid, and Organic Matter of Two Fish Meals, Two Poultry By-Product Meals, Soybean Meal, and Distiller's Dried Grains with Solubles in Practical Diets for Sunshine Bass, Morone chysops $\times$ M. saxatilis. Journal of the World Aquaculture Society, 39, 352-363. https://doi.org/10.1111/j.1749-7345.2008.00174.x

[20] Rhodes, M.A., Yu, D., Zhou, Y. and Allen Davis, D. (2015) Use of Lipid-Extracted Distillers Dried Grains with Solubes (DDGS) in Diets for Pacific White Shrimp. North American Journal of Aquaculture, 77, 539-546. https://doi.org/10.1080/15222055.2015.1067263

[21] Schaeffer, T.W., Brown, M.L. and Rosentrater, K.A. (2011) Effects of Dietary Distillers Dried Grains with Solubles and Soybean Meal on Extruded-Pellet Characteristics and Growth Responses of Juvenile Yellow Perch. North American Journal of Aquaculture, 73, 270-278. https://doi.org/10.1080/15222055.2011.593461

[22] Brown, P.B., Kasushik, S.J. and Peres, H. (2008) Protein Feedstuffs Originating from Soybeans. In: Lim, C.E., Webster, C.D. and Sheng-Lee, C., Eds., Alternative Protein Sources in Aquaculture Diets, The Haworth Press, Binghamton, New York, 205-223.

[23] Brown, P.B. (2008) Utilization of Soy Products in Diets of Freshwater Fish. In: Lim, C.E., Webster, C.D. and Sheng-Lee, C., Eds., Alternative Protein Sources in Aquaculture Diets, The Haworth Press, Binghamton, New York, 225-260. 
[24] Takii, K., Shimeno, S., Nakamura, M., Itoh, Y., Obatake, A., Kumai, H. and Takeda, M. (1989) Evaluation of Soy Protein Concentrate as a Partial Substitute for Fish Meal Protein in Practical Diet for Yellow Tail. Proceedings of the $3 r d$ International Symposium on Feeding and Nutrition in Fish, 28 August-1 September 1989, Toba, 281-288.

[25] Stickney, R.R., Hardy, R.W., Koch, K., Harrold, R., Seawright, D. and Massee, K.C. (1996) The Effects of Substituting Selected Oilseed Protein Concentrates for Fish Meal in Rainbow Trout Oncorhynchus mykiss Diets. Journal of the World Aquaculture Society, 27, 57-63. https://doi.org/10.1111/j.1749-7345.1996.tb00594.x

[26] Mambrini, M., Roem, A.J., Cravedi, J.P., Lalles, J.P. and Kaushik, S.J. (1999) Effects of Replacing Fish Meal with Soy Protein Concentrate and of DL-Methionine Supplementation in High-Energy, Extruded Diets on the Growth and Nutrient Utilization of Rainbow Trout, Oncorhynchus mykiss. Journal of Animal Science, 77, 2990-2999. https://doi.org/10.2527/1999.77112990x

[27] Day, O.J. and Plascencia Gonzalez, H.G. (2000) Soybean Protein Concentrate as a Protein Source for Turbot Scophthalmus maximus L. Aquaculture Nutrition, 6, 221-228. https://doi.org/10.1046/j.1365-2095.2000.00147.x

[28] Storebakken, T., Shearer, K.D. and Roem, A.J. (2000) Growth, Uptake and Retention of Nitrogen and Phosphorus, and Absorption of Other Minerals in Atlantic Salmon Salmo salar Fed Diets with Fish Meal and Soy-Protein Concentrate as the Main Sources of Protein. Aquaculture Nutrition, 6, 103-108. https://doi.org/10.1046/j.1365-2095.2000.00135.x

[29] Takagi, S., Shimeno, S., Hosokawa, H. and Ukawa, M. (2001) Effect of Lysine and Methionine Supplementation to a Soy Protein Concentrate Diet for Red Sea Bream Pragus major. Fisheries Science, 67, 1088-1096. https://doi.org/10.1046/j.1444-2906.2001.00365.x

[30] Walker, A.B., Sidor, I.F., O'Keefe, T., Cremer, M. and Berlinksy, D.L. (2010) Partial Replacement of Fish Meal with Soy Protein Concentrate in Diets of Atlantic Cod. North American Journal of Aquaculture, 72, 343-353. https://doi.org/10.1577/A09-085.1

[31] Zhao, H., Jiang, R., Xue, M., Xie, S., Wu, X. and Guo, L. (2010) Fishmeal Can Be Completely Replaced by Soy Protein Concentrate by Increasing Feeding Frequency in Nile Tilapia (Oreochromis niloticus GIFT Strain) Less than 2g. Aquaculture $\mathrm{Nu}$ trition, 16, 648-653. https://doi.org/10.1111/j.1365-2095.2009.00708.x

[32] Ngandzali, B.O., Zhou, F., Xiong, W., Shao, Q.J. and Xu, J.Z. (2011) Effect of Dietary Replacement of Fish Meal by Soybean Protein Concentrate on Growth Performance and Phosphorus Discharging of Juvenile Black Sea Bream, Acanthopagrus schegelii. Aquaculture Nutrition, 17, 526-535.

https://doi.org/10.1111/j.1365-2095.2010.00835.x

[33] Lopez, L.M., Flores-Ibarra, M., Banuelos-Vargas, I., Galaviz, M.A. and True, C.D. (2015) Effect of Fishmeal Replacement by Soy Protein Concentrate with Taurine Supplementation on Frowth Performance, Hematological and Biochemical Status, and Liver Histology of Totoaba Juveniles (Totoaba macdonaldi). Fish Physiology and Biochemistry, 41, 921-936. https://doi.org/10.1007/s10695-015-0058-5

[34] Mohd Faudzi, N., Yong, A.S.K., Shapawi, R., Senoo, S., Biswas, A. and Takkii, K. (2018) Soy Protein Concentrate as an Alternative in Replacement of Fish Meal in the Feeds of Hybrid Brouper, Brown-Marbled Grouper (Epinephelus fuscoguttatus) x Giant Grouper (E. lanceolatus) Juvenile. Aquaculture Research, 49, 431-441. https://doi.org/10.1111/are.13474

[35] Voorhees, J.M., Barnes, M.E., Chipps, S.R. and Brown, M.L. (2018) Dietary Biopro- 
cessed Soybean Meal Does Not Affect the Growth of Exercised Juvenile Rainbow Trout (Oncorhyncus mykiss). Journal of Animal Research and Nutrition, 3, 6. https://doi.org/10.21767/2572-5459.100050

[36] Kasper, C.S., Watkins, B.A. and Brown, P.B. (2007) Evaluation of Two Soybean Meals Fed to Yellow Perch (Perca flavescens). Aquaculture Nutrition, 13, 431-438. https://doi.org/10.1111/j.1365-2095.2007.00494.x

[37] Davies, S.J. and Morris, P.C. (1997) Influence of Multiple Amino Acids Supplementation on the Performance of Rainbow Trout, Oncorhynchus mykiss (Walbaum), Fed Soya Based Diets. Aquaculture Research, 28, 65-74. https://doi.org/10.1111/j.1365-2109.1997.tb01316.x

[38] Hardy, R.W. (2010) Utilization of Plant Proteins in Fish Diets: Effects of Global Demand and Supplies of Fishmeal. Aquaculture Research, 41, 770-776. https://doi.org/10.1111/j.1365-2109.2009.02349.x

[39] Francis, G., Makkar, H.P.S. and Becker, K. (2001) Antinutritional Factors Present in Plant-Derived Alternate Fish Feed Ingredients and Their Effects in Fish. Aquaculture, 199, 197-227. https://doi.org/10.1016/S0044-8486(01)00526-9

[40] USDA (U.S. Department of Agriculture) (2017) Oil Crops Yearbook. http://usda.mannlib.cornell.edu/MannUsda/viewDocumentInfo.do?documentID=1 290

[41] Hart, S.D., Brown, B.J., Gould, N.L., Robar, M.L., Witt, E.M. and Brown, P.B. (2010) Predicting the Optimal Dietary Essential Amino Acid Profile for Growth of Juvenile Yellow Perch with Whole Body Amino Acid Concentrations. Aquaculture Nutrition, 16, 248-253. https://doi.org/10.1111/j.1365-2095.2009.00659.x

[42] Steele, R.G., Torrie, J.H. and Dickey, D.A. (1997) Principles and Procedures of Statistics, a Biometric Approach. 3rd Edition, McGraw-Hill, New York.

[43] Rinchard, J., Becheret, R. and Dabrowski, K. (2008) Growth, Survival, and Body Composition of Yellow Perch Juveniles Fed Commercial and Experimental Diets. North American Journal of Aquaculture, 70, 74-79. https://doi.org/10.1577/A06-047.1

[44] Robinson, E.H. and Li, M.H. (2008) Replacement of Soybean Meal in Channel Catfish, Ictalurus punctatus, Diets with Cottonseed Meal and Distiller's Dried Grains with Solubles. Journal of the World Aquaculture Society, 39, 521-527. https://doi.org/10.1111/j.1749-7345.2008.00190.x

[45] Kwasek, K., Dabrowski, K., Ware, K., Reddish, J.M. and Wick, M. (2012) The Effect of Lysine-Supplemented Wheat Gluten-Based Diet on Yellow Perch Perca flavescens (Mitchill) Performance. Aquaculture Research, 43, 1384-1391. https://doi.org/10.1111/j.1365-2109.2011.02941.x

[46] Gaylord, T.G. and Barrows, F.T. (2009) Multiple Amino Acid Supplementations to Reduce Dietary Protein in Plant-Based Rainbow Trout, Oncorhynchus mykiss, Feeds. Aquaculture, 287, 180-184. https://doi.org/10.1016/j.aquaculture.2008.10.037

[47] Furuya, W.M., Pezzato, L.F., Barros, M.M., Pezzato, A.C., Furuya, V.R.B. and Miranda, E.C. (2004) Use of Ideal Protein Concept for Precision Formulation of Amino Acid Levels in Fish-Meal-Free Diets for Juvenile Nile Tilapia (Oreochromis niloticus L.). Aquaculture Research, 35, 1110-1116.

https://doi.org/10.1111/j.1365-2109.2004.01133.x 